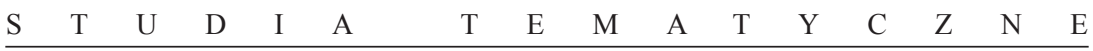

\title{
BETWEEN LAW AND POLITICS: MUSLIM RELIGIOUS PRACTICES IN SWISS PUBLIC SCHOOLS
}

Historically, Switzerland has been known for its humanitarian tradition as well as its progressive approach towards civil liberties, especially the freedom of religion. Currently, the country is confronted with a strong political movement that aims at restricting these civil rights of certain minority groups, in particular Muslims. This has led to several limitations to their religious practices, some of them even approved by popular vote. From a legal point of view, the question arises which role this shift in politics plays in the Federal Supreme Court's interpretation of the fundamental right to freedom of religion granted by the Swiss Constitution in cases regarding Muslims. By means of a case study of the field of public education, this paper examines how the political environment influences the relevant case law. After presenting the theoretical foundations underlying the relationship between law, politics and the Swiss judiciary, this paper elaborates on the evolution of the jurisprudence regarding limitations of Muslims' religious customs in public schools and identifies the underlying tendencies as well as political influence. ${ }^{1}$

* Master of Law (University of Basel); PhD Student in Law at the University of Zurich, Rämistrasse 74, 8001 Zürich, Switzerland, e-mail: fabienne.bretscher@rwi.uzh.ch

${ }^{1}$ It should be noted that there are of course other factors which can impact the Federal Supreme Court's jurisprudence, but they are not analysed in this paper. 


\section{THE SWISS JUDICIARY BETWEEN LAW AND POLITICS}

In order to understand the role of the Swiss judiciary and how it is positioned in the political landscape, this section first presents a short typology of Swiss democracy. Subsequently, the main features of the Federal Supreme Court (FSC), Switzerland's highest court, are introduced.

\subsection{A SHORT ACCOUNT OF SWISS DEMOCRACY}

Switzerland is based on a democratic system mostly known for its strong direct democratic instruments. ${ }^{2}$ This emphasis on direct democracy influences the interpretation of the principle of separation of powers in Switzerland. Differently from other democracies, the power is not only divided among the legislative, executive and judicial branches of the government, but a significant share lies also with the people. ${ }^{3}$ This is expressed in the Swiss Constitution, which states that "subject to the right of the People and the Cantons, the Federal Assembly [i.e. the Parliament] is the supreme authority of the Confederation."4 Due to this emphasis on popular sovereignty, it is thus not surprising that the legislative power, which disposes of direct democratic legitimacy based on the election of its members by the people, enjoys a predominant position compared to the other two branches of the government: ${ }^{5}$ it is primarily the Federal Assembly which disposes of instruments to

${ }^{2}$ For the historical origins, see Wolf Linder, Swiss Democracy: Possible Solutions to Conflict in Multicultural Societies (Basingstoke: Palgrave Macmillan, $3^{\text {rd }}$ ed., 2010), 95 ff.

${ }^{3}$ Giovanni Biaggini, “\$17: Gewaltenteilung im Verfassungsstaat," in Staatsrecht, eds. Giovanni Biaggini, Thomas Gächter, and Regina Kiener (Zürich: Dike, $2^{\text {nd }}$ ed., 2015), 193 ff., 204.

${ }^{4}$ Art. 148(1) of the Swiss Constitution (SCst) of 18 April 1999, available online: <https:// www.admin.ch/opc/en/classified-compilation/19995395/index.html $>$ [accessed: 29.06.2017].

${ }^{5}$ Regina Kiener, “§18: Die Bundesversammlung als Parlament des Bundes,” in Staatsrecht, eds. Giovanni Biaggini, Thomas Gächter, and Regina Kiener (Zürich: Dike, $2^{\text {nd }}$ ed., 2015) 206 ff.; see also Art. 169 SCst, according to which the parliament exercises oversight over the Federal Council (Bundesrat) and the federal courts. 
control the other two branches of the government, while control over the legislative power is seen as being mostly exercised by the people. ${ }^{6}$

\subsection{THE FEDERAL SUPREME COURT}

The FSC is the "supreme judicial authority of the Confederation." Differently from other countries, Switzerland does not have a specific constitutional court, instead the FSC decides on a range of different matters within the ambit of international, federal and cantonal law. ${ }^{8}$ Although having original competences, it acts as an appeal body in disputes in civil, criminal and public law. ${ }^{9}$ Yet, many issues, which are seen as political, are excluded from the jurisdiction of the FSC, for example decisions in the area of public security. ${ }^{10}$ Grounds of appeal are not limited to violations of the Swiss Constitution, but can also include violations of federal law, international law and certain areas of cantonal law. ${ }^{11}$

Despite this ample jurisdiction, the FSC, influenced by the strong emphasis on popular sovereignty and democratic legitimacy in the Swiss political system, finds itself in a significantly weaker position than the Federal Assembly. The latter has a weighty influence on the FSC, in particular by means of the power to elect its judges for only a limited period of six years. ${ }^{12}$ On the one hand, this provides them with a high democratic legitimacy. ${ }^{13}$ At the same time, this politicises

${ }^{6}$ Pierre Tschannen, "Wem gehört die Verfassung? Neuer Streit um die Gewaltenteilung," Zeitschrift des bernischen Juristenvereins 143 (2007): 793 ff., 796.

${ }^{7}$ Art. 188(1) SCst.

${ }^{8}$ Art. 189(1) SCst.

${ }^{9}$ Art. 72 ff. of the Swiss Federal Supreme Court Act (SFSCA) of 17 June 2005, available online: <https://www.admin.ch/opc/de/classified-compilation/20010204/index.html> [accessed: 29.06.2017].

${ }^{10}$ See for example the list in Art. 83 SFSCA.

${ }^{11}$ See Art. 95 ff. SFSCA.

${ }^{12}$ Art. 168 and 157(1) SCst; for the term of office, see Art. 145 SCst. It is important to emphasise that there are no restrictions on re-elections.

${ }^{13}$ See Regina Kiener, “\$21: Das Bundesgericht und weitere richterliche Behörden,” in Staatsrecht, eds. Giovanni Biaggini, Thomas Gächter, and Regina Kiener (Zürich: Dike, $2^{\text {nd }}$ ed., 2015), 269 ff., 277. 
the selection process, in particular because the Federal Assembly deliberately respects the proportional representation of the main political parties on the basis of their suggestions. As a consequence, judges at the FSC are de facto required to be members of a political party or at least have close ties to one. Often, the qualifications of a candidate are of lesser importance than her or his political affiliation. ${ }^{14}$ Although this election procedure is a result of Switzerland's democratic tradition, it can be strongly criticised for interfering with the principle of the rule of law. ${ }^{15}$ In particular, the independence and impartiality of the judiciary seems to be in danger of being negatively influenced by such politicisation of the election process. ${ }^{16}$

\section{THE FEDERAL SUPREME COURT}

AND MUSLIM RELIGIOUS PRACTICES IN PUBLIC SCHOOLS:

BETWEEN POLITICS AND THE PROTECTION

OF FUNDAMENTAL RIGHTS

After setting the political and institutional context in which the FSC operates, this part aims at taking a closer look at the decisions adopted in a today extremely sensitive area: Muslim religious practices. The Muslim population in Switzerland has increased from zero in 1960 to approximately 350,000 people in 2015 , which amounts to $5.1 \%$ of the resident population. ${ }^{17}$ Although today about one third of Muslims living in Switzerland possess Swiss citizenship, ${ }^{18}$ Muslims as a group are gener-

${ }^{14}$ See Daniela Wüthrich, "Bedeutung der Parteizugehörigkeit bei den Bundesrichterwahlen," Justice - Justiz - Giustizia 2 (2015).

${ }^{15}$ For further details, see Pascal Mahon, and Roxane Aurélie Schaller, "L'élection des juges entre tradition démocratique et exigences de l'Etat de droit," Parlament-Parlement - Parlamento 2 (2013): 5 ff.

${ }^{16}$ For details, see Regina Kiener, Richterliche Unabhängigkeit (Bern: Stämpfli 2001), $270 \mathrm{ff}$.

${ }^{17}$ See Federal Statistical Office, "Ständige Wohnbevölkerung ab 15 Jahren nach Religionszugehörigkeit," available online: <https://www.bfs.admin.ch/bfsstatic/dam/ assets/1822034/master $>$ [accessed: 25.10.2017].

${ }^{18}$ Ibid. 
ally associated with immigration and foreign identity, ${ }^{19}$ and Islamophobia is increasing, ${ }^{20}$ which is even reflected in the Swiss Constitution. In 2009, the people approved a popular initiative launched by the Swiss People's Party (SVP) which prohibits the construction of minarets in Switzerland. ${ }^{21}$ Additionally, a popular initiative prohibiting the wearing of the burqa has been approved in 2013 in one canton, the Ticino. Now, a popular initiative on the issue has been launched on the federal level. ${ }^{22}$ In a similar spirit, in recent years the public discussion surrounding immigration departed from grouping immigrants according to their countries of origin and constructed a Muslim minority in Switzerland, which is perceived as a problem and a threat. ${ }^{23}$

In the area of public education, this has led to a decreasing willingness to accommodate Muslim religious practices and to heated debates on the extent to which those practices can be limited..$^{24}$ A recent example is the controversy surrounding the question whether the refusal of two Muslim students to shake their female teacher's hand should be accommodated or not. ${ }^{25}$ It appears thus interesting to take a closer look at

${ }^{19}$ See Anaïd Lindemann, and Jörg Stolz, "Use of Islam in the Definition of Foreign Otherness in Switzerland: A Comparative Analysis of Media Discourses Between 1970-2004," Islamophobia Studies Journal 2/1 (2014): 44 ff. For further information regarding the situation of Muslims in Switzerland, see Marco Giugni, Matteo Gianni, and Noémi Michel, "Entre demandes de reconnaissance et politique d'accommodation: les orientations culturelles, sociales et politiques des musulmans en Suisse," available online: $<\mathrm{http}$ ://www. nfp58.ch/files/downloads/Schlussbericht_Giugni.pdf> [accessed: 25.10.2017].

${ }^{20}$ See for example Urs Dahinden, Carmen Koch, Vinzenz Wyss, and Guido Kehl, "Representation of Islam and Christianity in the Swiss Media," Journal of Empirical Theology 24 (2011): $197 \mathrm{ff}$.

${ }^{21}$ See Art. 72(3) SCst.

${ }^{22}$ For an overview, see Humanrights.ch, "Debatte zum Burkaverbot in der Schweiz," available online: <http://www.humanrights.ch/de/menschenrechte-schweiz/inneres/ gruppen/religioese/burkaverbot-schweiz> [accessed: 29.06.2017].

${ }^{23}$ See Patrik Ettinger, and Kurt Imhof, "Ethnisierung des Politischen und Problematisierung religiöser Differenz," available online: <http://www.nfp58.ch/files/news/114_nfp58_ schlussbericht_imhof.pdf> [accessed: 29.06.2017].

${ }^{24}$ See also Johannes Reich, "Switzerland: Freedom of creed and conscience, immigration, and public schools in the postsecular state - compulsory coeducational swimming instruction revisited," International Journal of Constitutional Law 7/4 (2009): 754 ff.

${ }^{25}$ Dina Sambar, and Joël Hoffmann, "Therwiler Schüler verweigern Handschlag offenbar weiter," Tagesanzeiger 27.5.2016, available online: <http://www.tagesanzeiger.ch/schweiz/ 
how this situation might have influenced the FSC's jurisprudence on this matter. Focusing on students, this section aims at presenting the relevant jurisprudence of the FSC and how decisions were influenced by the political situation in Switzerland. In the relevant jurisprudence on Muslim religious practices in public schools, three different phases can be identified: the first decision on dispensations from swimming classes in 1993, the second decision on the same issue in 2008, which reversed the standing case law, and two decisions in 2013 and 2015 on students who were prohibited from wearing the headscarf. ${ }^{26}$

\subsection{DISPENSATION FROM SWIMMING CLASSES: A FIRST DECISION}

The FSC was first confronted with a case concerning Muslim religious practices in the school environment in $1993 .{ }^{27} \mathrm{~A}$ father of a Muslim girl, who then attended the second grade, requested that the school exempts his daughter from mixed-sex swimming classes. He argued that Islam prohibits her from swimming with boys. While the school and the cantonal instances did not grant his request, the FSC found that the refusal of exemption violated the child's right to freedom of religion.

The FSC stated that according to its standing case law on religiously motivated exemptions from school, the accommodation of religious practices finds its limits in the efficient organization of the school as well as in the religious freedom of other students. By balancing the different interests in question, the FSC arrived at the conclusion that only when the education of the child was restricted in such a way that it would inhibit the equality of chances could the best interest of the child require denying a dispensation. This was, in the FSC's view, not the case as swimming classes did not represent an indispensable part of the school curriculum. The FSC took a clear position in stating that

standard/Therwiler-Schueler-verweigern-Handschlag-offenbar-weiter/story/14283666> [accessed: 29.06.2017].

${ }^{26}$ Unless stated otherwise, all translations in this section are the author's.

${ }^{27}$ Decision of the FSC, 18 June 1993, BGE 119 Ia 178. 
there is no legal obligation for religious minorities to assimilate to local customs and ways of life..$^{28}$

This decision was met with such strong opposition that one scholar stated that "[h]ardly any other decision [...] regarding the role of religion was met with such persistent and harsh criticism, mainly in the public arena and the mass media." ${ }^{29}$ The FSC was reprimanded for not sufficiently taking into account the aspect of gender equality, namely the allegedly paternalistic approach of the Islamic rule in question. ${ }^{30}$ Furthermore, it was claimed that the FSC avoided touching on the political dimension of the issue, i.e. the integration of foreign nationals. ${ }^{31}$ One commentator stated for example that it is "difficult to understand [...] when small and smallest minorities can always and solely demand tolerance from the majority supporting the state." ${ }^{32}$

\subsection{A RECONSIDERATION OF THE JURISPRUDENCE ON EXEMPTIONS FROM SWIMMING CLASSES}

Fifteen years later, in 2008, the FSC appears to have abided by the criticism, taking a very much different perspective on the issue: this time the father of two boys, attending the fourth and fifth grade, requested a dispensation from mixed-sex swimming classes. Although the dispensation of Muslim girls and boys was generally granted by schools after the above-discussed judgment of 1993, the canton Schaffhausen, which like all Swiss cantons disposes of autonomy in educational matters, decided to reverse this practice, basing its decision on a socio-cultural change. ${ }^{33}$ The FSC followed this approach emphasising

${ }^{28}$ BGE 119 Ia $178,196$.

${ }^{29}$ Reich, "Switzerland: Freedom of creed," 759.

${ }^{30}$ Paul Zweifel, "Religiöse Symbole und Kleidervorschriften im Zwielicht: zu BGE 116 Ia 252 und 119 Ia 178," Zeitschrift des bernischen Juristenvereins 132 (1995): 591 ff., 596.

${ }^{31}$ Hans Peter Moser, "Bemerkungen zum Urteil," Schweizerisches Zentralblatt für Staats- und Verwaltungsrecht (1994): 24 ff., 39.

${ }^{32}$ Zweifel, Religiöse Symbole, 597 (emphasis in the original), translation by the author.

${ }^{33}$ Decision of the FSC, 24 October 2008, BGE 135 I 79, 82. 
that the situation since the last leading decision in 1993 had changed regarding two main issues.

First, swimming could not be seen as a dispensable school subject anymore. This was in particular motivated by the ratification and entering into force of the United Nations Convention on the Rights of the Child for Switzerland in $1997,{ }^{34}$ which requires making the best interest of the child paramount for all measures considering children. ${ }^{35}$ According to the FSC, mixed-sex swimming and sports classes fulfil an important socialising function. Exemption from such classes would make children of Muslim faith "outsiders already at school." ${ }^{36}$ Interestingly, the exact same wording can be found in a commentary on the 1993 judgment, ${ }^{37}$ which exemplifies the influence of the criticism on the change of approach. By following this line of reasoning, the FSC showed that it was influenced by the general shift in public discourse: Muslims are no longer seen as just another religious group in Switzerland whose needs should be accommodated if possible, but as a separate group. ${ }^{38}$ Consequently, based on the FSC's analysis, the problem seems not to lie with the lack of tolerance for difference by the school authorities or fellow students, but with the Muslim students..$^{39}$

Intrinsically linked to this change of perspective is the second issue, on which the FSC based its change of jurisprudence: the growing concerns about the integration of immigrants and their descendants. What was an ancillary argument in 1993 became central for the decision of $2008 .{ }^{40}$ The FSC motivated the heightened attention given to the topic in particular with legislative changes, namely the inclusion of concerns

${ }^{34}$ It is worth noting that the said Convention already entered into force in 1990, thus before the first decision on swimming classes, however, it was not considered relevant by the FSC, as Switzerland had not ratified it yet.

${ }^{35}$ BGE 135 I 79, 87.

${ }^{36}$ Ibid., translation by the author.

${ }^{37}$ Zweifel, Religiöse Symbole, 595.

${ }^{38}$ See Ettinger and Imhof, Ethnisierung.

${ }^{39}$ See also Sylvie Guichard, "De la liberté de croyance à l'obligation de s'intégrer: les arrêts du Tribunal fédéral sur les dispenses de cours de natation pour des élèves musulmans," Aktuelle Juristische Praxis (2014): 983 ff., 988.

${ }^{40}$ See also Guichard, "De la liberté," 985 f. 
about integration in the Foreign Nationals Act, ${ }^{41}$ which had entered into force in January 2008. Article 4 of the said act in the version in force at that time defined "the co-existence of the resident Swiss and foreign population on the basis of the values of the Federal Constitution and mutual respect and tolerance" as the aim of integration. Furthermore, it stated that "foreign nationals are required to familiarise themselves with the social conditions and way of life in Switzerland." This, according to the FSC's interpretation, contrasts with its earlier statement declaring that there is no legal obligation for religious minorities to assimilate to local customs and ways of life.

Linked to this change of legislation, the FSC's focus thus shifted from treating the request for exemption from swimming classes just as any other religiously motivated exemption to seeing Muslims as a group mostly formed by foreign nationals, who need to integrate. ${ }^{42}$ Along these lines, the FSC stated that in recent years, concerns on integration have especially grown for Muslims in Switzerland, which, based on an article entitled "Switzerland on the way to becoming a Muslim state" published by a Jewish news service, were said to amount to 400,000 at the time, most of them foreigners. ${ }^{43}$ This "multicultural school environment," according to the FSC, required increased measures in order to familiarise children from other cultures with the social conditions prevailing in Switzerland. ${ }^{44}$

Based on official documents issued by the Federal Administration in the context of the adoption of the then new Foreign Nationals Act, the FSC determined that it is "the duty of the state to ensure a minimum degree of inner cohesion of state and society, which is necessary for a harmonic cohabitation characterised by respect and tolerance. ${ }^{~} 45$ It went on to specify that

it can and must be expected by foreign nationals to be ready to live together with the native population and to accept the Swiss legal order

${ }^{41}$ Federal Act on Foreign Nationals of 16 December 2005, the version in force at the time of the decision is available online: $<$ https://www.admin.ch/opc/de/official-compilation/2007/5437.pdf> [accessed: 29.06.2017].

${ }^{42}$ See also Guichard, "De la liberté," $986 \mathrm{f}$.

${ }^{43}$ BGE 135 I 79, 88, translation by the author.

${ }^{44}$ Ibid., translation by the author.

${ }^{45} \mathrm{Ibid}$., translation by the author. 
with its democratic and constitutional principles - which the state must preserve also against culturally motivated diverging claims - as well as the local social and societal realities. ${ }^{46}$

This perspective, however, ignores the fact that "the conflict between religious and legal obligations provoked by topics taught at public schools is generally independent of the citizenship of the individual in question." "47 Already in the 1993 decision, the FSC had recognised this fact and compared the case to its previous jurisprudence, for example on exemptions of members of the World Wide Church of God. ${ }^{48}$

Centred on the two discussed issues as well as the important role of public school in the process of social inclusion, ${ }^{49}$ the FSC then changed its approach and, with a very narrow majority of three to two, did not see an unjustified restriction of the students' right to freedom of religion.

\subsection{PROHIBITION OF THE WEARING OF THE HEADSCARF:}

CHANGING THE APPROACH TO MUSLIMS AGAIN?

A slightly different and less restrictive approach, at least from Muslim students' point of view, can be observed in the jurisprudence concerning prohibitions of the wearing of the Muslim headscarf in public schools, where the FSC found a violation of the students' right to freedom of religion in two cases from 2013 and 2015. The cases are similar to the "swimming cases" in the sense that an exemption from a rule applying to all students is requested: the schools had generally prohibited the covering of the head during school time in a school regulation. This was, in the schools' opinion, necessary for a respectful interaction among students and teachers. ${ }^{50}$ Requests for exceptions based on religious grounds brought forward by Muslim girls were

\footnotetext{
${ }^{46}$ Ibid., translation by the author.

${ }^{47}$ Reich, "Switzerland: Freedom of creed," 763.

${ }^{48}$ Decision of the FSC, 19 February 1988, BGE 114 Ia 133.

${ }^{49}$ See also Reich, "Switzerland: Freedom of creed," $758 \mathrm{f}$.

${ }^{50}$ Decision of the FSC, 11 July 2013, BGE 139 I 280.
} 
not granted and they were excluded from school. Compared to the "swimming case" of 2008 presented above, the "headscarf cases" show a very different approach: The emphasis on integration in the sense of assimilation, which can be found in the "swimming case" of 2008 seems to have been replaced by a focus on integration in the sense of inclusion and accommodation. ${ }^{51}$

This can be observed in the first case decided in 2013, where the FSC focused on the requirement of a sufficiently high-ranked legal basis, i.e. a law approved by the legislative branch of the communal government. The restriction of the student's right to freedom of religion was seen as severe since a prohibition of the headscarf in school would confront the student with the decision to either contravene a state or a religious rule. Such tensions can be against the best interest of the child. ${ }^{52}$ This reasoning stands in a stark contrast to the elaborations made in the "swimming case" in 2008: The tensions between following state or religious (and family) rules, on which the FSC based its argumentation, are also present in the "swimming case." Contrary to the decision in 2013, the FSC did not, however, mention the conflict the students found themselves in in 2008. Interestingly, the students concerned, confronted in the end with the decision to follow the FSC's decision or the religiously imposed rule not to participate in the swimming lessons, chose the latter. Yet, despite controversies, they were, not excluded from school. ${ }^{53}$

In December 2015, the FSC took the chance to address the fundamental question whether such restriction was necessary and proportionate. ${ }^{54}$ It clearly showed that its focus was on religion, and not as in the "swimming case" of 2008, on immigration and integration. This can be seen already in the extensive elaborations on the meaning and function of religious freedom and tolerance, starting with the Edict of Milan in

${ }^{51}$ For an overview of the different uses of the term integration see Kristin Henrard, "Tracing Visions on Integration and/of Minorities: An Analysis of the Supervisory Practice of the FCNM," International Community Law Review 13 (2011): 333ff.

${ }^{52}$ Ibid., 285.

${ }^{53}$ Guichard, "De la liberté," 988.

${ }^{54}$ Decision of the FSC, 11 December 2015, BGE 142 I 49. 
IV century. ${ }^{55}$ For the proportionality exam, the FSC stated, against the standing case law of the European Court of Human Rights (ECtHR), ${ }^{56}$ that the principle of neutrality of public schools did not give sufficient reasons for a prohibition of headscarves for students. ${ }^{57}$ With regard to the public interest to protect the rights of others, the FSC stated that a prohibition of the wearing of religious symbols might be suitable for protecting the negative religious freedom of fellow students, i.e. their right not to be exposed to pressure to follow a certain religious practice. ${ }^{58}$ Nevertheless, in the absence of attempts to proselytise, the wearing of religious symbols by others must be tolerated, since the school should represent an open environment for different religious and non-religious beliefs. ${ }^{59}$

The FSC did even not shy away from touching upon the controversial topic of gender equality and headscarves. The FSC had stated in a decision on the wearing of the headscarf by a teacher in 1997 that it was "difficult to reconcile the wearing of the headscarf with the principle of gender equality." ${ }^{60}$ In the present decision, the FSC seems to have changed this approach and decided that it is not up to a court to answer the question why a woman wears the headscarf, specifying that the motivation of Muslim women for wearing the headscarf was very diverse and ranged from compulsion to choice. ${ }^{61}$ According to this changed

${ }^{55}$ BGE 142 I 49, 52; for a critical account see Johannes Reich, "Urteilsbesprechung Bundesgericht, II. öffentlich-rechtliche Abteilung, 11. Dezember 2015, 2C_121/2015," Schweizerisches Zentralblatt für Staats- und Verwaltungsrecht 117 (2016): 369 ff., 383 f.

${ }^{56}$ See for example ECtHR Aktas v. France (no. 43563/08; 30 June 2009).

${ }^{57}$ BGE 142 I 49, 70; for the different approach taken with regard to teachers see ECtHR, Dahlab v. Switzerland (no. 42393/98; 15 February 2001); decision of the FSC, 12 November 1997, BGE 123 I 296. The case concerned a Muslim primary school teacher who was prohibited from wearing the headscarf during work because of the strict separation between religion and state (secularism/laïcité) in the canton in question (Geneva). Neither the FSC nor the ECtHR found a violation of the teacher's right to freedom of religion in this case.

${ }^{58}$ BGE 142 I 49, 67.

${ }^{59} \mathrm{BGE} 142 \mathrm{I} 49,71 \mathrm{f}$.

${ }^{60}$ BGE 123 I 296, para. 4.b.cc, translation by the author.

${ }^{61}$ See also Mirina Grosz, "Schweizerisches Bundesgericht, II. öffentlich-rechtliche Abteilung, Urteil vom 11. Dezember 2015, 2C_121/2015 i.S. Schulgemeinde St. Margrethen gegen A. und B.D., Tragen des islamischen Kopftuchs im Schulunterricht," Aktuelle Juristische Praxis (2016): 958 ff., 969. 
approach, the wearing of the headscarf as such did thus not contradict the constitutional guarantee of gender equality. ${ }^{62}$ As in the concrete case there was no indication that the student was forced to wear the headscarf, the FSC qualified the exclusion from school as disproportionate. Rather, the participation in school also of religious students was seen as necessary in order to achieve equality of chances and integration. ${ }^{63}$

It is especially this part where it becomes obvious that the FSC's "headscarf cases" do not attribute the same meaning to the word integration as the "swimming case" of 2008: while the latter speaks of integration in the sense of assimilation of foreign nationals to Swiss customs, the former use the word in the sense of inclusion. ${ }^{64}$ Moreover, differently from the "swimming case," the FSC does not explicitly make the link between Islam and foreign nationals in the "headscarf cases." Rather, the FSC based its reasoning on the right to freedom of religion and the idea of tolerance, which lies at the heart of this human rights guarantee. In this sense, the right to freedom of religion shall, according to the FSC, fulfil an integrating function, which prevents the exclusion of religious minorities and facilitates their integration in a religiously pluralistic society. ${ }^{65}$

3. THE FEDERAL SUPREME COURT

AS A DEFENDER OF MUSLIMS' RIGHT TO FREEDOM

OF RELIGION AGAINST POLITICAL POLARISATION?

From this presentation of the FSC's decisions on Muslim religious practices in public schools, the question arises whether the political environment influenced the various changes in jurisprudence. For the 2008 "swimming case," the coinciding political developments are mentioned by the FSC itself in the decision, namely the inclusion of concerns about integration in the Foreign Nationals Act, which had

\footnotetext{
${ }^{62}$ For a critical account, see Reich, "Urteilsbesprechung,” 386.

${ }^{63}$ BGE 142 I 49, 75 f.

${ }^{64}$ See Henrard, "Tracing Visions," $335 \mathrm{ff}$.

${ }^{65}$ BGE 142 I 49, 52; see also Grosz, "Schweizerisches Bundesgericht," 971.
} 
entered into force in January 2008. This act specified that "foreign nationals need to confront the social circumstances and living conditions in Switzerland." ${ }^{66}$ For the FSC, this new legislation, together with the strong criticism of its earlier decision, served as a trigger to reverse its standing case law, which had seemingly entered in contradiction with the Foreign Nationals Act. This concerned in particular the statement declaring that there is no legal obligation for religious minorities to assimilate to local customs and ways of life. ${ }^{67}$

Yet, in the elaborations of the "headscarf decisions" the focus seems to have returned from Muslims as immigrants, who need to familiarise themselves with the social conditions prevailing in Switzerland, ${ }^{68}$ to Muslims as a religious minority, in need of protection against exclusion. ${ }^{69}$ Looking at the political landscape in Switzerland, the situation has not, however, changed significantly since 2008. Rather, Switzerland has undergone further political polarisation during the last years. ${ }^{70}$ The right-wing party, the SVP, has more than doubled its electorate ${ }^{71}$ as it has taken over old xenophobe parties and moved further to the right. ${ }^{72}$ The SVP today advances its nationalist-conservative political programme in a populist style, which guarantees a lot of media attention and helps it to further increase its electorate. ${ }^{73}$ This involves a strong focus on foreigners in general and Muslims in particular. ${ }^{74}$

The question thus arises whether the FSC, whose members are elected by the Federal Assembly, where the SVP is in the majority,

${ }^{66}$ Art. 4 of the Foreign Nationals Act.

${ }^{67}$ BGE 119 Ia 178, 196.

${ }^{68}$ BGE 135 I 79, 88.

${ }^{69}$ BGE 142 I 49, 52.

${ }^{70}$ See also Linder, Swiss Democracy, $146 \mathrm{f}$.

${ }^{71}$ This becomes obvious when looking at the development of the number of seats in the Swiss Nationalrat, the parliamentary chamber representing the population. Over the course of the last twenty years, the SVP went from 29 to 65 seats. Just in the elections of 2015, the SVP has won 11 seats.

${ }^{72}$ Linder, Swiss Democracy, 146.

${ }^{73}$ See already Oscar Mazzoleni, Nationalisme et Populisme en Suisse - La Radicalisation de la 'Nouvelle' UDC (Lausanne: Presses Polytechniques et Universitaires 2003).

${ }^{74}$ Regarding the tendency to link Islam to foreign identity in Switzerland, see Lindemann and Stolz, Islam. 
can withstand this political influence, in particular in cases regarding controversial topics. Until now, the Federal Assembly has never refused the re-election of a federal judge. Yet, in several instances the Federal Assembly warned judges who were involved in debated decisions with an intentionally low approval rate. ${ }^{75}$ This happened for example in the elections subsequent to the "crucifix case," 76 where the FSC decided that a crucifix on the wall of a public school violated the principle of religious neutrality. ${ }^{77}$ Furthermore, also the members of the division, which took a controversial decision in the area of immigration, have been specifically deleted from the election list by some members of the Federal Assembly. ${ }^{78}$

Given that the "headscarf decisions" were taken against the tendencies observable in the political environment, they could be seen as a defence of Muslims' right to freedom of religion, counterbalancing the political polarisation. This can be noted when considering that the increasing power of the SVP has also reflected on the definition of integration in Swiss legislation. Although the definition of integration in the Foreign Nationals Act mentioned by the FSC in its 2008 decision has not changed, one can find more restrictive definitions in other official documents. In 2014, for example, the Federal Assembly has approved a complete revision of the Swiss Citizenship Act. ${ }^{79}$ The criteria for integration, which is a requirement for obtaining Swiss citizenship, specified in this Act and the relevant regulations are significantly more restrictive than in 2008.

Differently from its 2008 decision on the "swimming case," the FSC did not, however, mention these coinciding political developments in the "headscarf decisions." Instead, it showed the limits set to politi-

${ }^{75}$ Kiener, “\$21: Das Bundesgericht,“ 282.

${ }^{76}$ Decision of the FSC, 26 September 1990, BGE 116 Ia 252.

${ }^{77}$ See Federal Gazette 1990 N 2520 f.

${ }^{78}$ See Federal Gazette 2014 N 1879; Gerold Steinmann, "Denk-würdige Wiederwahl der Bundesrichterinnen und Bundesrichter," Schweizerisches Zentralblatt für Staats- und Verwaltungsrecht 116 (2015): $1 \mathrm{f}$.

${ }^{79}$ Federal Act on the Acquisition and Loss of Swiss Citizenship of 29 September 1952. The revised version entered into force on 1 January 2018 and is available online: $<$ https:// www.admin.ch/opc/de/official-compilation/2016/2561.pdf $>$ [accessed: 29. 06. 2017]. 
cal actors, following from fundamental rights, in particular the right to freedom of religion. Taking into account that the trend of restricting Muslims' religious practices seems far from over, ${ }^{80}$ it remains to be seen which approach the FSC will choose in future decisions. Considering the criticism the court has received recently, in particular for taking "political" decisions, ${ }^{81}$ the FSC will have to prove that differently from the "swimming case" in 2008, it will take its decisions independently and impartially, despite the strong politicisation of its election process.

\section{REFERENCES}

Biaggini, Giovanni. “§17: Gewaltenteilung im Verfassungsstaat.” In Staatsrecht, edited by Giovanni Biaggini, Thomas Gächter, and Regina Kiener. Zürich: Dike, $2^{\text {nd }}$ ed., 2015.

Dahinden, Urs, Carmen Koch, Vinzenz Wyss, and Guido Kehl. "Representation of Islam and Christianity in the Swiss Media." Journal of Empirical Theology 24 (2011).

Ettinger, Patrik, and Kurt Imhof. "Ethnisierung des Politischen und Problematisierung religiöser Differenz." available online: $<$ http://www.nfp58.ch/ files/news/114_nfp58_schlussbericht_imhof.pdf $>$.

Giugni, Marco, Matteo Gianni, and Noémi Michel. "Entre demandes de reconnaissance et politique d'accommodation: les orientations culturelles, sociales et politiques des musulmans en Suisse." available online: <http://www. nfp58.ch/files/downloads/Schlussbericht_Giugni.pdf $>$.

${ }^{80}$ See for example the two complaints pending before the FSC concerning the prohibition of the burqa in one Swiss canton ("Rekurse vor Bundesgericht: «Anti-Burka»-Gesetz im Tessin kann in Kraft treten,” Neue Zürcher Zeitung 15 June 2016, available online: <http:// www.nzz.ch/schweiz/rekurse-vor-bundesgericht-anti-burka-gesetz-im-tessin-kann-in-krafttreten-ld.89165> [accessed: 29. 06. 2017]) or the popular initiative in one Swiss canton demanding a prohibition of headscarves in schools ("Walliser SVP fordert Kopftuchverbot an Schulen," Neue Zürcher Zeitung 22 February 2016, available online: <http://www.nzz. ch/schweiz/walliser-svp-fordert-kopftuchverbot-an-schulen-1.18699499> [accessed: 29. 06. 2017]).

${ }^{81}$ See for example Rudolf Strahm, "Richter, lasst die Politik," Tagesanzeiger 23 August 2016, available online: <http:/www.tagesanzeiger.ch/schweiz/standard/richter-lasst-diepolitik/story/30089053> [accessed: 29. 06. 2017]. 
Grosz, Mirina. "Schweizerisches Bundesgericht, II. öffentlich-rechtliche Abteilung, Urteil vom 11. Dezember 2015, 2C_121/2015 i.S. Schulgemeinde St. Margrethen gegen A. und B.D., Tragen des islamischen Kopftuchs im Schulunterricht." Aktuelle Juristische Praxis (2016).

Guichard, Sylvie. "De la liberté de croyance à l'obligation de s'intégrer: les arrêts du Tribunal fédéral sur les dispenses de cours de natation pour des élèves musulmans." Aktuelle Juristische Praxis (2014).

Henrard, Kristin. "Tracing Visions on Integration and/of Minorities: An Analysis of the Supervisory Practice of the FCNM." International Community Law Review 13 (2011).

Kiener, Regina. "§18: Die Bundesversammlung als Parlament des Bundes." In Staatsrecht, edited by Giovanni Biaggini, Thomas Gächter, and Regina Kiener. Zürich: Dike, $2^{\text {nd }}$ ed., 2015.

Kiener, Regina. "§21: Das Bundesgericht und weitere richterliche Behörden." In Staatsrecht, edited by Giovanni Biaggini, Thomas Gächter, and Regina Kiener. Zürich: Dike, $2^{\text {nd }}$ ed., 2015.

Kiener, Regina. Richterliche Unabhängigkeit. Bern: Stämpfli 2001.

Lindemann, Anaïd, and Jörg Stolz, "Use of Islam in the Definition of Foreign Otherness in Switzerland: A Comparative Analysis of Media Discourses Between 1970-2004." Islamophobia Studies Journal 2/1 (2014).

Linder, Wolf. Swiss Democracy: Possible Solutions to Conflict in Multicultural Societies. Basingstoke: Palgrave Macmillan, $3^{\text {rd }}$ ed., 2010.

Mahon, Pascal, and Roxane Aurélie Schaller. "L'élection des juges entre tradition démocratique et exigences de l'Etat de droit." Parlament - Parlement - Parlamento 2 (2013).

Mazzoleni, Oscar, Nationalisme et Populisme en Suisse - La Radicalisation de la 'Nouvelle'UDC. Lausanne: Presses Polytechniques et Universitaires 2003. Moser, Hans Peter. "Bemerkungen zum Urteil." Schweizerisches Zentralblatt für Staats- und Verwaltungsrecht (1994).

Reich, Johannes. "Urteilsbesprechung Bundesgericht, II. öffentlich-rechtliche Abteilung, 11. Dezember 2015, 2C_121/2015.” Schweizerisches Zentralblatt für Staats- und Verwaltungsrecht 117 (2016).

Reich, Johannes. "Switzerland: Freedom of creed and conscience, immigration, and public schools in the postsecular state - compulsory coeducational swimming instruction revisited." International Journal of Constitutional Law 7/4 (2009).

Sambar, Dina, and Joël Hoffmann. "Therwiler Schüler verweigern Handschlag offenbar weiter." Tagesanzeiger 27.5.2016, available online: 
$<$ http://www.tagesanzeiger.ch/schweiz/standard/Therwiler-Schueler-verweigern-Handschlag-offenbar-weiter/ story/14283666>.

Tschannen, Pierre. "Wem gehört die Verfassung? Neuer Streit um die Gewaltenteilung." Zeitschrift des bernischen Juristenvereins 143 (2007).

Wüthrich, Daniela. "Bedeutung der Parteizugehörigkeit bei den Bundesrichterwahlen." Justice - Justiz - Giustizia 2 (2015).

Zweifel, Paul. "Religiöse Symbole und Kleidervorschriften im Zwielicht: zu BGE 116 Ia 252 und 119 Ia 178." Zeitschrift des bernischen Juristenvereins 132 (1995).

\author{
POMIĘDZY PRAWEM A POLITYKĄ: \\ MUZUŁMAŃSKIE PRAKTYKI RELIGIJNE \\ W SZWAJCARSKICH SZKOŁACH PUBLICZNYCH
}

\title{
Streszczenie
}

Szwajcaria stoi obecnie w obliczu silnego ruchu politycznego, którego celem jest ograniczenie praw obywatelskich niektórych grup mniejszościowych, w szczególności muzułmanów. Doprowadziło to do różnych ograniczeń ich praktyk religijnych. Niektóre z tych ograniczeń zostały nawet zaakceptowane $\mathrm{w}$ głosowaniu powszechnym. $\mathrm{Z}$ prawnego punktu widzenia powstaje pytanie o rolę, jaką ta zmiana $\mathrm{w}$ polityce odgrywa w przyjmowanej przez Federalny Sąd Najwyższy interpretacji podstawowego prawa do wolności religii zagwarantowanego w szwajcarskiej Konstytucji w sprawach dotyczących muzułmanów. Artykuł analizuje wpływ środowiska politycznego na orzecznictwo odnosząc się do spraw z zakresu edukacji publicznej. W konkluzji stwierdza się, że chociaż Sąd początkowo wpisywał się w polityczny trend ograniczania podstawowych praw muzułmanów, to jednak w ostatnich decyzjach zajmuje mocniejsze stanowisko przeciwko takim tendencjom.

Słowa kluczowe: wolność religijna; Islam; edukacja publiczna; sądownictwo; Szwajcaria

Key words: religious freedom; Islam; public education; judiciary; Switzerland 